\title{
Sciendo
}

\section{DO REMITTANCES REDUCE POVERTY IN KOSOVO? - A COUNTERFACTUAL ANALYSIS}

Arbëresha Loxha

\begin{abstract}
Migration and remittances are argued to be an effective mechanism for mitigating poverty, as well as a coping mechanism for disadvantaged households with no or little employment and earning opportunities in Kosovo. A considerable part is reported to be directed towards consumption and very little for investment or enterpreneurship purposes. The high dependence of households on remittances suggests that poverty rates would be much higher without the safety net provided through migration and remittances. The conventional approach of empirically estimating determinants of remittances, including those focusing on Kosovo, treats both remittance and migration behaviour as independent decisions. Empirically estimating determinants of remittances while overlooking the importance of variables that influenced the decision to migrate will leave out these determinants and also bias the results. Hence, this study treats migration and remittance decision as a joint process and focuses on the household. More precisely, it analyses the impact that remittances and migration have on the poverty in Kosovo, in a hypothetical case, without remittances and migration using data from the Household Budget Survey 2011.
\end{abstract}

Due to the potential presence of selection bias, this study uses a two-stage Heckman-type selection procedure which suggests that there is no selection bias. The study develops counterfactual consumption estimates for remittance recipient households through the use of survey bootstrap procedure to predict the consumption of households in the case of no remittances. The results support the hypothesis that remittances increase the consumption of recipient households. The poverty rate would be higher for a considerable proportion of households in the case of no remittances. The poverty rates would increase particularly in rural areas. The novelty of this study lies on the methodological approach chosen to investigate the impact of remittances on poverty in Kosovo. In contrast to previous analysis, this study controls for potential selection bias and empirically assesses whether the expectations on the poverty reducing effect of remittances in Kosovo hold.

Keywords: International Migration, Remittances, Poverty

Arbëresha Loxha, $\mathrm{PhD}$

Executive Director

Group for Legal and Political Studies (GLPS)

Professor

AAB College

E-mail: arbresha.loxha@gmail.com

JEL classification: $F 22, F 24,132$ 


\section{INTRODUCTION}

During the last decade, Kosovo's economic growth has been solid, growing at double-digit rates during the early years of the post-conflict period and an average of 3.4 percent since 2008 . The growth was mainly attributed to donor-funded reconstruction efforts and international transfers (WB 2010). In 2017, 18 percent of population is reported to live below the national poverty line and 5.1 percent as extremely poor (KAS, 2018). Although the poverty rates have decreased since 2011 (29.7\% reported to be poor), Kosovo remains one of the poorest countries in Europe and the South-East Europe (SEE) region. Moreover, disparities in poverty rates are evident amongst regions. The impact of economic performance on the standard of living is considered to have been small as households are reported to spend the majority of their budget on food (38 percent) and shelter (31 percent) (WB and KAS 2011). At the same time, Kosovo has recorded persistently high unemployment rates of above 40 percent during the last decade and 29.6 percent of working age individuals (15-64) are reported to be unemployed in 2018 (KAS 2019). In this context, migration and remittances have been an effective mechanism for mitigating poverty in Kosovo, as well as a coping mechanism for disadvantaged households with no or little employment and earning opportunities. The high dependence of households on remittances suggests that poverty rates would be much higher without the safety net provided through migration and remittances (Loxha 2015).

Remittances are known for the potential important role they can play in terms of supporting the development efforts of recipient countries; however, their effect on development, to a large extent, depends on the sending country's context, migration selectivity and the recipient's use of such income (de Hass 2009). In countries with high poverty-as is the case for Kosovo-remittances have proven to alleviate poverty amongst recipient households (UNDP 2012). However, migrants may not come from the lowest quintiles of the income distribution; therefore, remittances may not flow towards the poorest. In such cases, it is not expected that remittances would have a large effect on poverty (Acosta et al 2007). Moreover, they can increase inequality amongst households in different regions, as migration may be only affordable to the better-off households (UNDP 2012; Acosta et al 2007). Remittances can contribute to higher investment in human and physical capital, and thus may also have a positive impact on sustainable human development as they improve the earning prospect of the new generation (Loxha 2015). However, remittances may create dependency and subsequently increase reservation wages hence negatively affecting the labour supply of recipients (UNDP 2012).

Considering the potential offsetting effects linked with an increased flow in remittances, it may be quite challenging to determine not only the magnitude of the potential development impact of remittances but also even the direction of such impact (Loxha 2015). Therefore, empirical evidence is necessary to determine the signs and magnitude of the different economic effects of the flow of remittances. The existing empirical evidence on the various development impacts of remittances is, however, still somewhat limited for Kosovo (lbid). Owing to the high dependence of Kosovo on remittances, it is of considerable importance for there to be a policy analysis studying the welfare implications of these flows. The contribution of this study is two-fold:

- First, it investigates the effect of remittances on poverty by adopting a counterfactual approach. This addresses a common limitation of the most empirical studies in the migration and remittances literature that treat both migration and remittances separately.

- Second, it investigates whether the expectations on poverty reducing effect and survival nature of remittances for the households in Kosovo holds true. Different from other existing studies on Kosovo, this study accounts for the counterfactual per consumption that the household would have had if the migrant had stayed at home.

The approach for the construction of counterfactual scenario is to estimate equations that predict per adult consumption levels of households that do not receive remittances and apply the estimated coefficients to the households that do receive remittances. This estimation enables comparison between the observed and predicted poverty rates in Kosovo and also across regions. The rest of the study is organised as follows: Section 2 reviews the theoretical and empirical work on relationship between migration, remittances and poverty. Section 3 provides a background on migration and remittances on Kosovo. Section 4 presents the data used in the study, as well as some useful descriptive statistics of the variables to be used in the empirical estimation. An explanation of the empirical methodology and the stages of implementation and respective requirements, adjustments and assumption are discussed in Section 5; the results of the regression estimation are presented in Section 6 and finally Section 7 concludes. 


\section{THEORETICAL AND EMPIRICAL REVIEW}

Theory has discussed several motives to remit and thus the impact of migration on poverty depends upon such motives (Loxha 2016). According to altruistic model, the amount remitted is affected by the income and size of the household whereby, the amount remitted should increase in cases when the household income decreases - due to adverse economic shocks - and decrease otherwise. An increase in migrants' income on the other hand is expected to increase remittances (Nilsson 2005; Hagen-Zanker and Siegel 2008). The remittances sent for altruism are more likely to influence poverty directly, as they help households smooth their consumption patterns and reduce the household expenditure burden.

The self-interest motives to remit are driven by the aspiration to inherit and/or future possibility of returning home (Nilsson 2005). Therefore, remittances sent for self-interest purposes increase with an increase in household income or possibility to return (Hagen- Zanker and Siegel 2008) as a result, such remittances are not expected to decrease poverty given they are more likely to be directed towards wealthier households. In addition, the motives to remit may be a mix of both altruism and self-interest known as the 'tempered altruism' (Nilsson 2005). According to this theory the motives for remitting are seen as an agreement between the migrant and the household aiming to be beneficial for both parties as explained earlier within the family framework of decision making and NELM (Lucas and Stark 1985). Remittances sent under this agreement are expected to decrease household poverty as it is expected to help them smooth consumption and also invest in projects with higher risk thus improve household utility if altruism motives remitting. If self-interest motive prevails then remittances are expected to flow towards wealthier households hence are not expected to affect poverty.

During the last decades, the number of empirical studies on the motivations to migrate and remit has considerably increased (Loxha 2016). However, a number of studies share a set of limitations. The limitations of the studies are two-fold:

First, the conventional empirical modelling strategies in migration and remittances literature generally treat migration and remittances as independent decisions (Loxha 2016; Shehaj, 2012). Moreover, according to Shehaj (2012), most studies focus in testing specific theoretical models of migration or remittances (Adams 1991, 2006, 2004; Sorensen 2004; Zhu and Luo 2007; Brown and Jimenez 2007). Findings of research suggest that none of the theories of migration alone can explain all the dynamics of migration and receipt of remittances (lbid). A number of studies concerned with determinants of remittances use data from surveys with migrants thus, in their estimations they only include individual migrants (Niimi et al. 2008; Roman 2013; Goschin and Roman 2012; Emanuel et al. 2012; Germenji et al. 2001; Amuedo-Dorantes and Pozo 2006). Some other studies that analyse decision to remit, use household living standard measurement surveys but base the analysis on a sample of migrant households only (Agrawal and Horowitz 2002; Garip 2006; Gubert 2002).

There is no conclusive evidence on which of the motives to remit prevails (Loxha 2016). Empirical studies find support for all the three motives: altruism (Agrawal and Horowitz 2002; Vanwey 2004; Osili 2007; Bouoiyour and Miftah 2014), self interest (HagenZanker and Siegel 2008; De Brauw et al. 2013; De la Briere et al. 2002), and tempered altruism (Lucas and Stark 1985; De Brauw et al. 2013; Amuedo-Dorantes and Pozo 2006; Bouoiyour and Miftah 2014; Batista and Umblijs 2014; De la Briere et al. 2002).

Garip (2006) argues that theoretical considerations and empirical findings suggest that migration and remittances could be interrelated. However, treatment of these two phenomena as interrelated is almost non-existent in the literature. The abovementioned study investigates interrelation of migration with remittances and findings support the need for jointly modelling migration and remittance behaviour, while taking into account potential endogeneity and sample selection biases. Shehaj (2012) on the other hand, argues that it is more appropriate to analyze the two phenomena as one decision as it would yield to more accurate determinants of remittances. Focusing only on the determinants of remittances thus omitting the importance of factors that affected the migration decision may bias the results in addition to leaving out important factors. Moreover, the study argues that linking both decisions can be argued to be more appropriate empirically for two main reasons: First, it makes it possible to control for potential endogeneity of the two decisions, considering the decision to remit as an important determinant of migration itself. According to Hagen-Zanker and Siegel (2007) most of the migrants in Albania migrate in order to remit. Second, it also allows modelling migration as a selection mechanism for remittances thus correcting for the selection-bias of the estimates.

Most of the evidence from existing studies with household data suggest that international migration and remittances have a significant effect on the poverty headcount, depth, and severity, but also disproportionately improve the income of the poorest 
poor (Adams 1991, 2004; Adams and Cuecuecha 2010; Sorensen 2004; Zhu and Luo 2007; Acosta et al. 2008; Gubert et al. 2010; Beyene 2011; Brown and Jimenez 2007; Shehaj 2012).

Research on the effect of remittances on poverty in Kosovo is rather scarce and most of the studies share the aforementioned limitations. Havolli (2009) analyze the determinants of remittances in Kosovo using migration survey gathered by Riinvest in 2006. Findings of this study suggest, amongst others, that the motive to invest and the various perceptions surrounding the business environment significantly determe remittances. Shaorshadze and Miyata (2010) analyze the effects of remittances and migration on consumption, poverty and inequality amongst households in Kosovo. Amongst others, the study finds that private transfers have significant effects in terms of improving welfare in Kosovo, and were allocated predominantly towards individuals with a truly low welfare level. Mollers and Meyer (2014) investigate the impact of migration on rural poverty and inequality in Kosovo based on a comparison with counterfactual migrant household incomes derived from Propensity Score Matching. The study finds that remittances have no impact on the extremely poor, but lift around $40 \%$ of migrant households above the vulnerability threshold.

\section{MIGRATION AND REMITTANCES IN KOSOVO: A BACKGROUND ANALYSIS}

Migration and remittances have been of considerable importance to the economy of Kosovo since the late 1960s. The literature on the Kosovar migration culture/history highlights four specific phases (Riinvest 2007):

a) Migration of Kosovar seasonal workers, unskilled, poorly educated/trained and from rural areas, mainly towards Germany and Switzerland based on special contracts on a temporary basis, characterized the first phase of migration;

b) Migration of better educated and skilled young men, from both urban and rural areas during 1989-1997 characterised the second phase of migraiton. One of the main motive was to escape the Yugoslav army services, specifically during the 1992-1995 Balkan wars, whilst the lay-off from jobs of many Kosovar citizens, resulting from the abolition of the autonomous status of Kosova in 1989, was recognised as another driver to migration;

c) The third phase of migration was the forced migration as a result of the massive population displacement with the 1998/99 war in Kosovo, during which time individuals mainly migrated to the neighbouring countries, such as Albania, Macedonia and Montenegro;

d) Finally, migration after 1999 characterises the current phase of migration.

During the post-conflict period, immigration policies towards Kosovars were more restrictive given the political stability recognised within Kosovo; therefore, migration during this period was mainly characterised by: a) asylum-seeking/illegal migration driven mainly by the motives of finding better economic and employment opportunities given the post-conflict socioeconomic situation in Kosovo; b) migration for family reunification purposes; and c) the legal migration of highly skilled and highly educated individuals for temporary study or work arrangements.

It is recognised widely that the Kosovo economy relies heavily on remittance flows from migrants, on average with more than 22 percent of households reporting reliance on remittances (UNDP 2014; KAS 2013). The report particularly notes that remittances are considered to represent the second largest source of income for remittance-receiving households, highlighting the crucial role they have had in helping a significant number of households to meet their basic consumption needs. The Diaspora is of key importance for stimulating growth and reducing macroeconomic imbalances in Kosovo. Kosovo ranked in top-10 percent of countries with high share of migrant remittances as a share of GDP, with remittances in 2011 accounting for 18 percent of GDP; whereas in 2017 is reported to account for 15.3 percent (WB 2012, 2019). Remittances have been one of the most important components of the balance of payments of Kosovo, and by December 2018 amounted to 800.5 million Euro (Table 1), marking an annual increase of 5.4 percent (CBK 2019).

Remittance use is largely geared towards basic consumption amongst recipients, with more than 90 percent spent on basic items, such as food, clothing, housing, durable goods, health and education (UNDP 2012). According to CBK (2013), remittances are acknowledged as one of the most important components in the financing of consumption in the country; however, government authorities report only limited direct investments by Diaspora. Regardless of the earned income of recipients or the profile of migrants, it is important to mention that remittances increase the gross income level of recipients, which subsequently increases the demand for consumption of products and services, normally resulting in an increase in the demand for local labour. Nevertheless, remittances can spoil recipient households, thus negatively affecting the labour market supply by 
Table 1: Remittances during period 2010-2018

\begin{tabular}{|ll|}
\hline Year & (mil $€$ ) \\
\hline 2010 & 584.3 \\
2011 & 584.8 \\
2012 & 605.6 \\
2013 & 620.8 \\
2014 & 622.3 \\
2015 & 665.5 \\
2016 & 691.0 \\
2017 & 759.2 \\
2018 & 800.5 \\
\hline
\end{tabular}

Source: Central Bank of Kosovo, 2012; 2019; Kosovo Agency of Statistics, 2018

increasing reservation wages. This may be one factor, amongst other reasons, explaining the large percentage of inactive individuals within the Kosovo population (Rodrigues and Tiongson 2001).

\section{DATA AND DESCRIPTIVE STATISTICS}

This study utilised data from the 2011 Household Budget Survey (HBS). HBS collects household consumption data, as well as household and individual characteristics. The survey is representative of the population of Kosovo, with the sample stratified on seven main regions, urban and rural areas. A total of 2,267 households (13,172 individuals) were interviewed.

However, only a total of 2,214 households have reported income more precisely, 2.6 percent did not respond on this question. Therefore, it is not clear whether they did not receive any of the specified sources of income or that they refused to respond. Around 32 percent of such households are classified as poor, thus given this study is concerned with poverty, in order to avoid dropping these observations it assumes that such households did not receive remittances. 16.4 percent of households in the sample received in-kind and/or cash remittances from members and non-members of the household during the last month before the survey.

This section aims to provide descriptive statistics of the variables used in the empirical analysis and accordingly to test for differences in these variables between the remittance recipient and non-recipient households. Figure 1 shows the share of households that receive remittances by regions. In two regions, Gjakova and Peja, the share is close to 20 percent, while in other regions it varies around 12 percent.

It is largely households with 10 or less members that receive remittances (95\%) and despite the fact that there are only about 0.4 percent of households with 20 or more members, none of them receives remittances. Moreover, it is generally households with 1 to 3 members that consist for the highest share of recipient households. More precisely, 36.4, 42.4 and 22.5 percent of households with 1, 2 and 3 members, respectively, received remittances. This could be due to these households being composed of (single) parents of the migrant and thus they may send remittances for altruism but also for inheritance motives. The amount of remittances generally ranges from 45 to 400 Euros and in most cases they amount for a relatively large share of total income and in particular if remittances are high. An examination of the incidence of remittance by age shows that around 29 percent of households with older heads (65 years old and over) received international remittances.

Figure 1: Share of households in the sample that receive remittances across regions (\%).

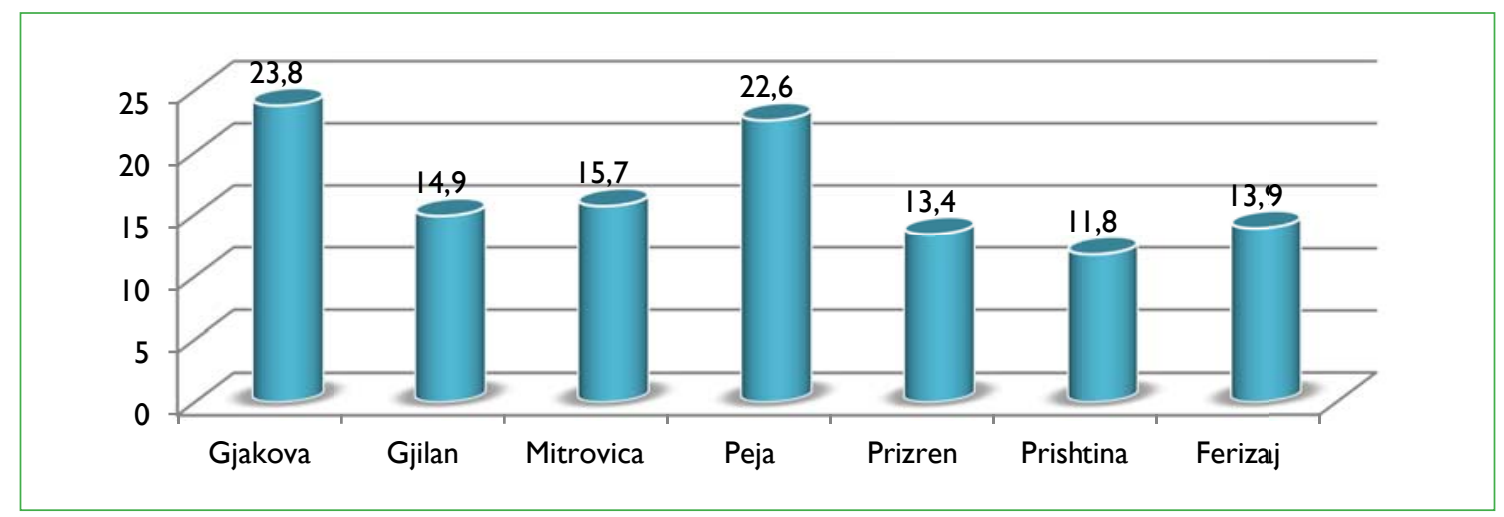

Source: Household Budget Survey 2011 and author's calculation 
Figure 2: Distribution of households that receive remittances across per adult equivalent consumption quintiles (\%)

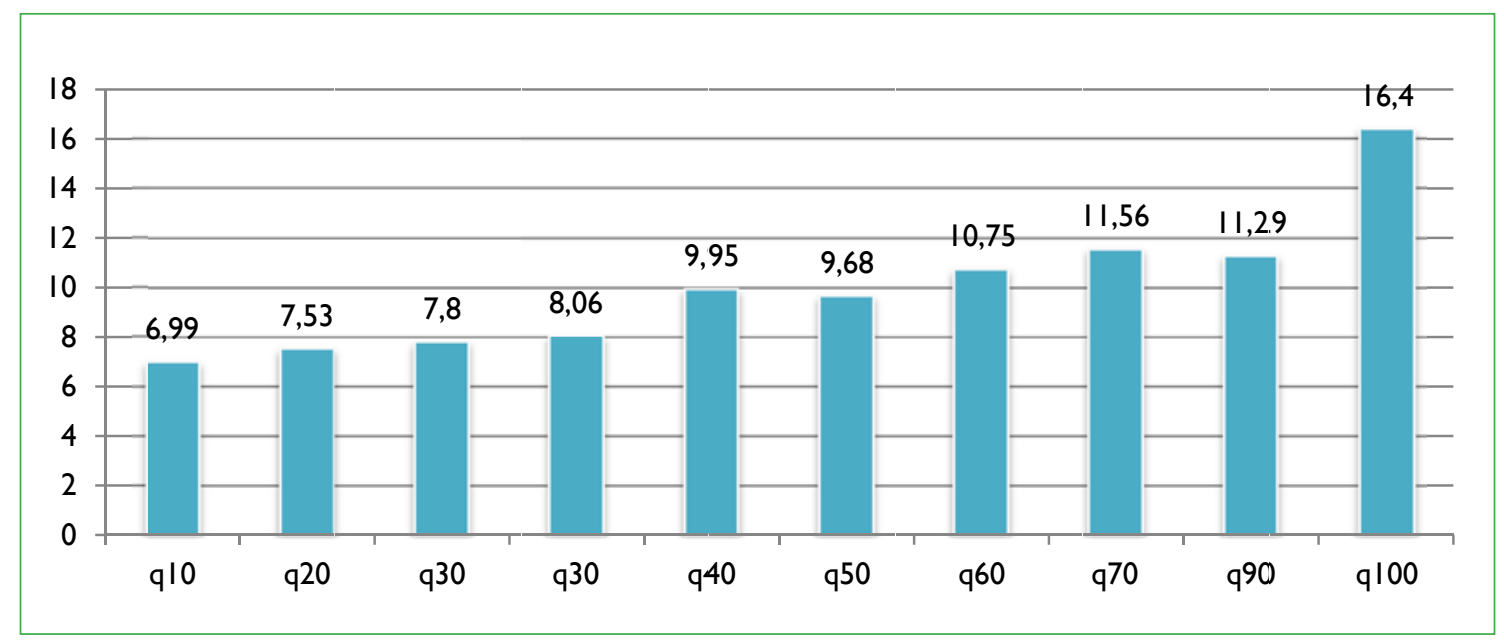

Source: Housholds Budget Survey 2011 and author's computations

Table 2 shows the distribution of remittances on total household income of recipient households according to region. On average, remittances are 71.1 percent of recipient households' income at the national level. The share of remittances in total income shows a pattern similar for the seven regions, with Peja showing the lowest share of 68 percent and Gjakova the highest with 74.5 percent. The figures indicate that the remittance recipient households have a relatively

Table 2: Share of remittances* in total household income in 2011 (\%)

\begin{tabular}{|cc|}
\hline Region & Mean \\
\hline Gjakova & 74.5 \\
Gjilan & 72.3 \\
Mitrovica & 71.1 \\
Peja & 68.1 \\
Prizreni & 71.4 \\
Prishtina & 70.5 \\
Ferizaj & 69.9 \\
Totali & 71.1 \\
\hline
\end{tabular}

Source: Household Budget Survey 2011 and authors calculations

* Remittances = Sent in cash and/or in kind by family and non family members high dependence on remittances; however, it should be noted that the income sent home by migrants is likely to over-estimate the real contribution of remittances as some migrants if they had stayed at home would have had a job. Figure 2 presents the distribution of households that receive remittances across the 10 consumption quintiles. The graph suggests that most of the households that receive remittances belong to the highest quintiles.

Table 3: Comparisons of weighted means of household characteristics between recipient (yes) and non-recipient (no) households

\begin{tabular}{|llcc|}
\hline Variables & \multicolumn{3}{c|}{ Mean Std. Deviation } \\
\hline Annual consumption & Yes & 952.5 & 608.9 \\
per adult equivalent & No & 899.7 & 538.5 \\
\hline Size of the household & Yes & 7.07 & 3.7 \\
& No & 7.5 & 3.8 \\
\hline Median age of adult & Yes & 37.4 & 12.2 \\
members & No & 35.1 & 9.7 \\
\hline Share of adult & Yes & 71.96 & 20.7 \\
members & No & 72.9 & 19.3 \\
\hline Dependency Ratio & Yes & 65.8 & 52.2 \\
& No & 59.2 & 52.5 \\
\hline Male ratio & Yes & 38.4 & 19.1 \\
& No & 44.5 & 16.3 \\
\hline Share of employed & Yes & 10.7 & 14.3 \\
shousehold members & No & 28.4 & 20.0 \\
\hline
\end{tabular}

Source: Housholds Budget Survey 2011 and author's computations 
With regard to the composition of households, Table 3 and 4 suggest that the recipient households have a lower adults and children, as well as a lower dependency ratio, when compared with non-recipients. The proportion of female-headed households is higher amongst recipient households, which may be the result of higher male migration. The number of fulltime employed members is higher among the nonrecipient households. Regarding the highest level of education in the family, the percentage of households with lower levels of education is higher among households that receive remittances, while the percentage of those with a higher level of education is higher among those households who do not receive remittances. This suggests that less educated household heads are more likely to receive remittances or to send someone abroad.

The Chi-square test was used to test for differences in the proportions of the binary variables between the groups of recipient and non-recipient households, and shows statistically significant differences, except for primary maximum level of education (Table 5). For continuous variables, a t-test of differences between the means of recipient and non-recipient households is significant for every variable, except for dependency ratio variable (Table 6). These results indicate that the households receiving remittances on average display significantly different characteristics from those that do not receive remittances.

It should be noted that across regions, the poverty

Table 4: Proportion of categorical variables for recipient (yes) and non-recipient (no) households

\begin{tabular}{|c|c|c|}
\hline Variables & Recipient Households (\%) & Non-recipient Households (\%) \\
\hline \multicolumn{3}{|l|}{ Dependent variable } \\
\hline Remittance Receipt & 16.4 & 83.6 \\
\hline \multicolumn{3}{|c|}{ Maximun level in education in a household } \\
\hline Less than primary & 24.5 & 11.4 \\
\hline Primary & 15.9 & 14.7 \\
\hline Secondary & 47.8 & 47.8 \\
\hline Tertiary & 11.8 & 21.0 \\
\hline \multicolumn{3}{|l|}{ Household characteristics } \\
\hline Female Headed Households & 20.2 & 7.2 \\
\hline \multicolumn{3}{|l|}{ Location } \\
\hline Household resides in rural areas & 42.7 & 57.1 \\
\hline \multicolumn{3}{|l|}{ Region } \\
\hline $\begin{array}{l}\text { Gjakova } \\
\text { Gjilan } \\
\text { Mitrovica } \\
\text { Peja } \\
\text { Prizren } \\
\text { Prishtina } \\
\text { Ferizaj }\end{array}$ & $\begin{array}{l}19.9 \\
12.1 \\
13.4 \\
18.9 \\
12.6 \\
12.1 \\
11.0\end{array}$ & $\begin{array}{c}12.5 \\
13.61 \\
14.1 \\
12.6 \\
16.0 \\
17.8 \\
13.4\end{array}$ \\
\hline
\end{tabular}

Source: Housholds Budget Survey 2011 and author's computations

Table 5: Comparison and tests of proportions of categorical variables between recipient and non-recipient of remittance households

\begin{tabular}{|lccc|}
\hline Variables & $\begin{array}{c}\text { Non-Accepting } \\
\text { Families }\end{array}$ & $\begin{array}{c}\text { Accepting } \\
\text { Families }\end{array}$ & Prob>Chi2 \\
\hline Female headed households & 0.202 & 0.072 & 0.000 \\
Maximum level of education in the household in less than primary & 0.245 & 0.114 & 0.000 \\
Maximum level of education in the household is primary & 0.159 & 0.147 & 0.555 \\
Maximum level of education in the household is secondary & 0.478 & 0.529 & 0.075 \\
Maximum level of education in the household is tertiary & 0.118 & 0.210 & 0.000 \\
Households resides in rural area & 0.427 & 0.571 & 0.000 \\
\hline
\end{tabular}

Source: Housholds Budget Survey 2011 and author's computations 
Table 6: T-test for comparison of means between recipient and non-recipient households

\begin{tabular}{|l|c|c|c|c|c|c|c|}
\hline Variables & $\mathrm{t}$ & $\mathrm{df}$ & Signif. & $\begin{array}{c}\text { Mean } \\
\text { Difference }\end{array}$ & $\begin{array}{c}\text { Std. Error } \\
\text { Difference }\end{array}$ & \multicolumn{2}{|c|}{$95 \%$ Conf. Interval } \\
\hline Icons & 3.943 & 2272 & 0.000 & 0.117 & 0.029 & 0.059 & Icons \\
\hline hhsize & -5.699 & 2272 & 0.000 & -0.933 & 0.164 & -1.254 & hhsize \\
\hline meadianage & 7.105 & 2272 & 0.000 & 4.876 & 0.686 & 3.530 & meadianage \\
\hline shareAdults & 3.398 & 2272 & 0.000 & 3.949 & 1.162 & 1.670 & shareAdults \\
\hline dependencyr & -0.062 & 2272 & 0.950 & -0.182 & 2.930 & -5.928 & dependencyr \\
\hline maleratio & -7.853 & 2272 & 0.000 & -8.619 & 1.098 & -10.772 & maleratio \\
\hline
\end{tabular}

Source: Housholds Budget Survey 2011 and author's computations

Table 7: Distribution of the poor among recipient and nonrecipient households across regions (\%)

\begin{tabular}{|l|c|c|}
\hline Region & Non-recipient & Recipient \\
\hline Gjakova & 38.9 & 37.3 \\
\hline Gjilan & 22.3 & 4.1 \\
\hline Mitrovica & 44.5 & 38.4 \\
\hline Peja & 31.9 & 24.1 \\
\hline Prizren & 26.7 & 20.7 \\
\hline Prishtina & 15.2 & 15.6 \\
\hline Ferizaj & 53.4 & 42.1 \\
\hline Total & 30.3 & 25.9 \\
\hline
\end{tabular}

Source: Housholds Budget Survey 2011 and author's computations

rates observed amongst households receiving remittances tend to be lower than those found in the general population, with the exception of Prishtina-although only slightly higher (Table 7).

\section{METHODOLOGY}

This section discusses the methodology used in this study in terms of performing a counterfactual analysis of the impact of remittances on poverty in Kosovo. The Heckman model can be estimated in two-ways: The Heckman's Two-Step Procedure and the Maximum Likelihood Estimation (MLE). Both have their advantages and drawbacks and there is no clearcut choice. The Heckman MLE estimator is consistent, efficient and has asymptotic normal distribution. "However it requires making a stronger assumption than in the two-step estimator, namely that $\mathrm{u}_{\mathrm{i}}$ and $\varepsilon_{\mathrm{i}}$ are distributed bivariate normal with mean zero, that $\mathrm{u}_{\mathrm{i}} \sim \mathrm{N}(0,1), \varepsilon_{\mathrm{i}} \sim \mathrm{N}\left(0, \sigma^{2}\right)$, and $\operatorname{corr}\left(\mathrm{u}_{\mathrm{i}}, \varepsilon_{\mathrm{i}}\right)=\rho$, and the selection and outcome equations are simultaneously estimated by maximum likelihood" (Shehaj 2012, p.7). Moreover, the full MLE is considered to be less robust than the two-step procedure due to it relying more heavily on the functional form assumption, and in some cases due to difficulties in getting it to converge (Ibid; Wooldridge 2002). On the other hand, in cases when data are problematic, the two-step model is expected to be more stable (Stata manual 2011; Shehaj 2012). This said, this study utilizes Heckman Two-Step Procedure.

The basic comparison of actual poverty rates including remittances with the rates calculated by subtracting the amount of remittances from household income is considered a naive approach. This approach suffers from an important shortcoming, as remittances are unlikely to be exogenous transfers of income but rather a substitute for pre-migration earnings of migrant. Therefore, actual household non-remittance income cannot be considered a good representation of the situation of the household prior to migration. Hence, it is important to consider the possibility that the migrant was employed and generated income in the home country. This means that remittances are more likely to be a substitute for home earnings had the migrant stayed at home. Normally, surveys do not provide information about the income of the household prior to the household member migrating. Thus, estimating the effects of migration and remittances on poverty requires taking into consideration the counterfactual consumption that the household would have had if the migrant had stayed at home; otherwise, the results would overestimate the real impact of migration and remittances on poverty reduction.

This study follows a three-step approach. First, it estimates household per adult equivalent consumption equations from observed values (initially estimating the probability of not being a remittance recipient which is then used to construct the Inverse Mill's Ratio). Second, it uses the consumption equations to simulate what the household consumption would have been if the household did not receive remittances. Third, using predicted consumption it calculates predicted poverty rates, which are then 
compared with observed ones. Accordingly, the analysis aims to test the significance of the following given hypotheses:

1) The total household consumption of the remittance-recipient households is higher when receiving remittances compared with the counterfactual scenario if the migrant stayed and worked in Kosovo.

2) The additional income from remittances decreases the incidence of poverty in Kosovo and across its regions.

The general approach for the construction of these counterfactuals would be to impute the prior-migration consumption using the coefficients from the estimation of the determinants of annual consumption per adult equivalent of households that do not receive remittances and apply the estimated coefficients to the households that do receive remittances. In line with the Statistical Office of Kosovo, which produces poverty figures on regular basis, annual consumption per adult equivalent in household (henceforth consumption) are used in regressions compared to per capita consumption, which is mainly used in other studies. The adult equivalences reflect the lower needs of children and also accounts for economies of scale. However, wide ranges of adult equivalence indicators exist in literature and all weights are arbitrary to a degree (Deaton 1997). Another drawback of this approach relates to the consumption of non-food items being not closely linked with age or gender. A drawback of per capita consumption on the other hand is the assumption that the needs of everyone in the household are the same and everyone receives an equal allocation of items consumed irrespective of age or gender. In addition, it ignores economies of scale. The steps involved in the estimation of the counterfactual consumption are presented below. If these two groups of households are selected randomly from the population, OLS estimation then may be used to establish the estimates, but it is expected that this is not the case.

\subsection{Estimation of per adult equivalent consumption of non-recipient households}

Considering that information on the characteristics of migrants is not available in the data utilised in this study, it is necessary to make some basic assumptions concerning the number and demographics of migrants. The per adult equivalent consumption in the no-remittance scenario is calculated by subtracting the reported monthly amount of per adult equivalent international remittances from the observed per capita consumption. Schiff (2006) argues that the construction of the counterfactual consumption should take into account the change in the household size due to migration. If data on the number of migrants are not available, Acosta et al. (2007) assumes that remittances are sent by a single adult family member employed in the home country. Moreover, it is assumed that education of the migrant is equal to the maximum level of education in the household.

If non-recipient households are not selected randomly from the pool of households but rather are selfselected, estimates based on the sample of households without migrants could suffer from selection bias unless corrected (Acosta et al 2007; Shehaj 2012)). This could be the case if the sub-sample of non-recipient households are not randomly drawn from the population but rather are self-selected on the basis of the identified determinants of non-remittance income/consumption. This leads to a non-zero mean of the error term of the outcome equation; thus, inconsistent estimates. In order to control for the potential selection bias, following Acosta et al. (2007), the Heckman two-step estimation is adopted.

This approach is similar to the case of addressing sample selection bias when the dependent variable is observed only for a restricted non-random sample. Although the consumption levels of the households are observed for all households in the sample, to estimate the counterfactual of the situation without remittances, only households that do not receive remittances are used.

Heckman's Two-Step Procedure (Heckman 1979): This process involves an estimation of two equations: the selection equation (Equation 1) and the outcome equation (Equation 2). The first stage of the approach is the specification of a selection equation that estimates the probability that a household does not receive remittances. Thus, in this equation, the dependent variable is a binary variable indicating whether or not the household does not receive remittances, estimated by probit regression.

$$
\begin{gathered}
\mathbf{M}_{\mathbf{i}}^{*}=\boldsymbol{\alpha}_{1}+\boldsymbol{\beta}_{1} \mathbf{X}_{\mathbf{i}}+\gamma_{1} \mathrm{H}_{\mathbf{i}}+\boldsymbol{\omega}_{1} \mathbf{Z}_{\mathbf{i}}+\mathbf{v i} \mathbf{i}^{\star}(\mathbf{1}) \\
\text { (no-remittances selection rule) }
\end{gathered}
$$

$$
\log Y i=\alpha_{2}+\beta_{2} X_{i}+\gamma_{2} H_{i}+\theta \lambda_{i}+\varepsilon_{2}(2)
$$

(outcome equation for non-recipient households)

The identification of this model requires at least one variable $\mathbf{Z i}$, which is related to the migration and remittances choice but which does not directly affect the consumption/earnings for non-recipient households. It is usual practice to include all the other 
variables (the $\mathrm{Xs}$ and $\mathrm{Hs}$ ) that are in the outcome equation in the selection equation to reduce the possibility of misspecification.

This estimation of the probability of being a nonrecipient is then followed by the construction of the inverse Mill's ratio $(\lambda i)$, derived from estimates of the probit regression. In the second step this ratio is included as an independent variable in the outcome Equation 2, which is estimated by OLS, thus allowing the remaining unexplained component $\varepsilon$ i to have the usual independently identically distributed (i.i.d.) properties. Assuming that the selection equation is specified correctly, the non-significance of this coefficient indicates there is no evidence that selection bias would have been present in straightforward one-stage OLS estimates.

The variable included in the non-remittances selection equation but excluded from the outcome equation in this study is the migrant network. Since it is not possible to calculate county level indicators, a measure of the percentage of households with migrants is included and is measured at the regional level. More precisely, it is defined as the percentage of households that receive remittances in the respective region in 2009 (a proxy for the presence of migrant networks), interacted with the number of adult males (15-34 years), as it is found to be most likely to migrate (would like to permanently settle in EU) by the EUPK 2012 survey and also will ensure variability at the household level. The HBS provides information on

Table 8: Description of variables used in regressions

\begin{tabular}{|c|c|}
\hline Variable & Description of variables \\
\hline \multicolumn{2}{|c|}{ Dependent Variables } \\
\hline Lcons & Natural logarithm of annual consumption per adult equivalent \\
\hline Recipient & 1 if household does not receive in cash or in kind remittances from anyone; 0 otherwise \\
\hline \multicolumn{2}{|c|}{ Independent variables } \\
\hline \multicolumn{2}{|c|}{ Households Charachteristics } \\
\hline hhsize & Number of members in household \\
\hline Hhsize2 & Squared term of the household size \\
\hline shareAdults & Share of members in household 15 years and older in total household members \\
\hline Medianage & Median age of adult members of the household \\
\hline Medianage2 & Squared term of the median age \\
\hline Dependencyr & Dependency ratio (share of children and elderly in total household size) \\
\hline Femalehead & 1 if household head is female; 0 if male \\
\hline \multicolumn{2}{|l|}{ Education } \\
\hline LessPrimary & 1 if household head has less than primary education; 0 otherwise \\
\hline Primary & 1 if household head has primary education; 0 otherwise \\
\hline Secondary & 1 if household head has secondary education; 0 otherwise \\
\hline Tertiary & 1 if household head has tertiary education; 0 otherwise. \\
\hline \multicolumn{2}{|l|}{ Labour market } \\
\hline shareofEmpl & Share of employed members in total household size \\
\hline Maleratio & Percentage of male members in total adults (Number of adult males/adults)*100 \\
\hline \multicolumn{2}{|c|}{ Identification variable } \\
\hline Networkproxy & Percentage of migrants in the region*the number of males in the household aged $15-65$ years \\
\hline \multicolumn{2}{|c|}{ Location/Region } \\
\hline UrbanRural & 1 if the household head resides in urban area, and 0 if in rural \\
\hline Gjakova & 1 if the household head resides in Gjakova; 0 otherwise \\
\hline Gjilan & 1 if the household head resides in Gjilan; 0 otherwise \\
\hline Mitrovica & 1 if the household head resides in Mitrovica; 0 otherwise \\
\hline Peja & 1 if the household head resides in Peja; 0 otherwise \\
\hline Prizren & 1 if the household head resides in Prizren; 0 otherwise \\
\hline Prishtina & 1 if the household head resides in Prishtina; 0 otherwise \\
\hline Ferizaj & 1 if the household head resides in Ferizaj; 0 otherwise \\
\hline
\end{tabular}

Source: Housholds Budget Survey 2011 and author's computations 
several assets purchased during the last 12 months, however, the information is available only for a small number of households. Therefore, it is more appropriate to interact the migrant network with the number of adult males in the household. The use of network proxy draws from migration network theory. The interaction between migrant networks with household assets or the number of adult males is used to allow for a different effect of migrant networks on households with different predispositions to migrate. In this respect, households with a larger number of adult males are more likely to send members abroad whereas the same holds true for those with more assets, who have a higher likelihood to afford the costs of migration. The estimated coefficients and the set of characteristics of the remittance non-recipient households are used to calculate the counterfactual non-remittance per adult equivalent consumption for the recipient households. These estimates and the actual values for non-remittance receiving households are used to calculate the levels of poverty that would have prevailed had no household received remittances in Kosovo. The descriptions of the variables to be used in the analysis are presented in Table 8.

Following Barham and Boucher (1998) a simulated error component is added to adjust the artificially lower variance for migrant families due to the use of predicted values. Authors proposed drawing a random error component with the same mean and standard deviation with the actual residuals of the model and add it to the predicted household income. In this study a survey bootstrap procedure is followed, and estimations take into account the population weights therefore the design of the survey and drawing 500 times. More precisely, the open source module bsweights (see Kolenikov, 2010 for details on the use of command) is used given the bootstrap Stata command does not include a weighting variable. The unobserved components are taken into account and included in the imputation of consumption counterfactuals, consequently providing a more appropriate non-remittance income (Shehaj 2012). Lastly, to predict consumption from this model the procedure given in Cameron and Trivedi (2010) for the prediction of $y$ when the dependent variable is $\log (y)$ in a Heckman or OLS model is followed.

\section{RESULTS}

This section presents the estimates of the counterfactual scenario with no remittances. This section is initiated by reviewing the estimates corresponding with the two-step model described in equations 1 and 2 , as reported in Table 9 . The study finds that $\lambda$ (lambda)
Table 9: Heckman Two Step Selection Model estimation results

\begin{tabular}{|c|c|c|}
\hline & $\begin{array}{l}\text { Outcome Equation } \\
\text { (real monthly consump- } \\
\text { tion per adult equivalent) }\end{array}$ & $\begin{array}{c}\text { Selection } \\
\text { Equation } \\
\text { (non-reciptient) }\end{array}$ \\
\hline Variables & $\begin{array}{c}\text { Coeficent } \\
\text { (Bootsrap Std.Err) }\end{array}$ & $\begin{array}{c}\text { Coeficent } \\
\text { (Bootsrap Std. } \\
\text { Err) }\end{array}$ \\
\hline hhsize & $\begin{array}{l}0.001^{* *} \\
(0.015)\end{array}$ & $\begin{array}{c}0.113^{* * *} \\
(0.038)\end{array}$ \\
\hline hhsize2 & $\begin{array}{c}0.000 \\
(0.007)\end{array}$ & $\begin{array}{l}-0.004^{* *} \\
(0.002)\end{array}$ \\
\hline femalehead & $\begin{array}{l}-0.016 \\
(0.053)\end{array}$ & $\begin{array}{c}-0.459^{* * *} \\
(0.129)\end{array}$ \\
\hline medianage & $\begin{array}{l}0.014^{* *} \\
(0.006)\end{array}$ & $\begin{array}{c}0.001 \\
(0.015)\end{array}$ \\
\hline medianage2 & $\begin{array}{l}-0.000 \\
(0.000)\end{array}$ & $\begin{array}{l}-0.000 \\
(0.000)\end{array}$ \\
\hline shareAdults & $\begin{array}{l}0.0024^{*} \\
(0.001)\end{array}$ & $\begin{array}{l}0.015^{* * *} \\
(0.0044)\end{array}$ \\
\hline dependencyr & $\begin{array}{l}-0.001 \\
(0.001)\end{array}$ & $\begin{array}{c}0.006^{* * *} \\
(0.002)\end{array}$ \\
\hline maleratio & $\begin{array}{l}-0.001 \\
(0.001)\end{array}$ & $\begin{array}{l}0.004^{*} \\
(0.002)\end{array}$ \\
\hline primaryM & $\begin{array}{c}0.160^{* * *} \\
(0.054)\end{array}$ & $\begin{array}{c}0.127 \\
(0.135)\end{array}$ \\
\hline secondaryM & $\begin{array}{c}0.227^{* * * *} \\
(0.048)\end{array}$ & $\begin{array}{c}0.000 \\
(0.113)\end{array}$ \\
\hline tertiaryM & $\begin{array}{c}0.418^{* * *} \\
(0.050)\end{array}$ & $\begin{array}{l}-0.054 \\
(0.133)\end{array}$ \\
\hline shareofEmpl & $\begin{array}{c}0.009^{* * * *} \\
(0.001)\end{array}$ & $\begin{array}{c}0.029 * * * \\
(0.002)\end{array}$ \\
\hline urbanrural & $\begin{array}{l}-0.022 \\
(0.033)\end{array}$ & $\begin{array}{l}0.212^{* *} \\
(0.083)\end{array}$ \\
\hline Gjilan & $\begin{array}{l}0.133^{* *} \\
(0.055)\end{array}$ & $\begin{array}{c}0.446^{* * *} \\
(0.139)\end{array}$ \\
\hline Mitrovica & $\begin{array}{l}-0.084 \\
(0.067)\end{array}$ & $\begin{array}{c}0.481^{* * *} \\
(0.137)\end{array}$ \\
\hline Peja & $\begin{array}{c}0.060 \\
(0.051)\end{array}$ & $\begin{array}{c}0.027 \\
(0.118)\end{array}$ \\
\hline Prizren & $\begin{array}{c}0.006 \\
(0.053)\end{array}$ & $\begin{array}{c}0.413^{* * *} \\
(0.115)\end{array}$ \\
\hline Prishtina & $\begin{array}{c}0.160^{* * *} \\
(0.056)\end{array}$ & $\begin{array}{c}0.452^{* * *} \\
(0.146)\end{array}$ \\
\hline Ferizaj & $\begin{array}{l}0.149 * * \\
(0.071)\end{array}$ & $\begin{array}{c}0.482^{* * *} \\
(0.155)\end{array}$ \\
\hline Networkprox & & $\begin{array}{l}-0.019 * * \\
(0.009)\end{array}$ \\
\hline Lambda & & $\begin{array}{c}0.008 \\
(0.136)\end{array}$ \\
\hline Constant & $\begin{array}{l}5.71 * * * \\
(0.281)\end{array}$ & $\begin{array}{c}-1.183^{* * *} \\
(0.632)\end{array}$ \\
\hline \multicolumn{3}{|c|}{$\begin{array}{l}\text { Observation Number } 2274 \\
\text { Censored Observations } 1902\end{array}$} \\
\hline
\end{tabular}

$* * * * * *$ Significant at $1 \%, 5 \%$ and $10 \%$, respectively 
is positive and insignificant - an indication that the sub-sample of remittance recipient households can be considered as a random draw from the population. These results suggest that the use of the Heckman model with selection controls is inappropriate and that OLS estimation will provide unbiased coefficients. Also, overall the results establish that this seems an appropriate model. The presence of migrant networks also seems to be negatively and significantly correlated with the likelihood of being a non-remittance recipient at convenient significant levels. The result and diagnostics of the estimation of the OLS regression are presented in Table 10.

The Ramsey's test of functional form indicates that the null hypothesis of correct functional form specification can not be rejected. Heteroscedasticity-robust standard errors are used instead of the usual standard errors. The normality test indicates that the errors are not normally distributed. Since the sample is relatively large, the study appeals to the Central Limit Theorem which states that OLS estimators satisfy asymptotic normality in large samples which enables us to use the $t$ and $F$ statistics (Wooldridge 2009). Moreover, using positively skewed variables such as consumption or wages and use of the natural logarithm of consumption helps in normalizing such variables. The reported $\mathrm{R}$-squared is 0.31 which can be considered reasonable for cross-sectional survey data.

\subsection{OLS results}

In the consumption equation most of the variables are significant and have the expected sign. The human capital variables, indicating the maximum level of education of the adults, have the expected sign and are highly significant. This is in line with human capital theory as well as salary figures in Kosovo according to education attainment; the average salary increases for higher attained levels of education, particularly for tertiary education attainment (UNDP 2012). More precisely, holding other variables constant, the higher the maximum level of education attained in the household, the higher is the effect on the level of consumption.

The median age variable is significant and has the expected sign however the squared term appears as insignificant. The share of the adults in the household is found to have a significant positive effect on the household consumption. Other things being equal, a 1 percentage point increase in the former is expected to increase consumption by 0.2 percent. The results also suggest that improved employment of household members significantly increases consumption per
Table 10: OLS regression results for estimation of per adult equivalent consumption on the sub-sample of nonrecipient households

\begin{tabular}{|c|c|}
\hline & $\begin{array}{c}\text { OLS } \\
\text { (real consumption per } \\
\text { adult equivalent) }\end{array}$ \\
\hline Variables & $\begin{array}{c}\text { Coeficent } \\
\text { (Robust Std.Err) }\end{array}$ \\
\hline hhsize & $\begin{array}{l}-0.001 \\
(0.012)\end{array}$ \\
\hline hhsize2 & $\begin{array}{l}-0.000 \\
(0.000)\end{array}$ \\
\hline femalehead & $\begin{array}{l}-0.014 \\
(0.046)\end{array}$ \\
\hline medianage & $\begin{array}{l}0.014^{* *} \\
(0.005)\end{array}$ \\
\hline medianage2 & $\begin{array}{l}-0.000 \\
(0.000)\end{array}$ \\
\hline ShareAdults & $\begin{array}{c}0.0024^{* *} \\
(0.001)\end{array}$ \\
\hline Dependencyr & $\begin{array}{c}-0.001 \\
(0.0004)\end{array}$ \\
\hline maleratio & $\begin{array}{l}-0.001 \\
(0.000)\end{array}$ \\
\hline primary & $\begin{array}{l}0.159 * * * \\
(0.041)\end{array}$ \\
\hline secondary & $\begin{array}{c}0.226^{* * *} \\
(0.035)\end{array}$ \\
\hline tertiary & $\begin{array}{l}0.418^{* * *} \\
(0.041)\end{array}$ \\
\hline ShareofEmpl & $\begin{array}{c}0.009^{* * *} \\
(0.006)\end{array}$ \\
\hline urbanrural & $\begin{array}{l}-0.022 \\
(0.022)\end{array}$ \\
\hline Gjilan & $\begin{array}{l}0.132^{* * *} \\
(0.041)\end{array}$ \\
\hline Mitrovica & $\begin{array}{c}-0.085^{* *} \\
(0.042)\end{array}$ \\
\hline Peja & $\begin{array}{c}0.060 \\
(0.043)\end{array}$ \\
\hline Prizren & $\begin{array}{c}0.000 \\
(0.038)\end{array}$ \\
\hline Prishtina & $\begin{array}{c}0.159 * * * \\
(0.039)\end{array}$ \\
\hline Ferizaj & $\begin{array}{c}-0.149^{* * *} \\
(0.05)\end{array}$ \\
\hline Constant & $\begin{array}{c}5.721^{* * *} \\
(0.192)\end{array}$ \\
\hline $\begin{array}{l}\text { No. of Observations } \\
\text { Ramsey RESET } \\
F(3,1879)=1.22 \\
\text { Prob }>F=0.3001\end{array}$ & $\begin{array}{c}1902 \\
\text { Jarque Bera Normality test } \\
\operatorname{Prob}>\text { chi } 2=0.000 \\
\operatorname{Pr}(\text { Skewness })=0.000 \\
\operatorname{Pr}(\text { Kurtosis })=0.000\end{array}$ \\
\hline
\end{tabular}

$* * * * * *$ Significant at $1 \%, 5 \%$ and $10 \%$ respectively 
additional working member. Most of the region dummies appear significant. Ceteris paribus, compared to those in Gjakova, households residing in Gjilan and Prishtina have a higher level of consumption. The opposite holds for those residing in Mitrovica and Ferizaj, as households residing in these regions. Location (urban/rural area), the dependency ratio, male ratio, female head and household size variables are not significant predictors of household consumption.

Having reviewed the results of the estimated regressions, we are now in a position to present the results of our poverty simulations, as reported in Table 11 and 12. The OLS regression of the logarithm of per annual consumption per adult equivalent is estimated with the use of the sub-sample of non-remittance recipient households, where the coefficients estimated are used to predict the consumption levels of the recipient households. In general, it is found

Table 11: Observed vs. predicted poverty headcount and poverty gap in urban and rural areas in percentages

\begin{tabular}{|c|c|c|c|}
\hline Subsample & $\begin{array}{l}\text { Poverty } \\
\text { Norms }\end{array}$ & $\begin{array}{c}\text { Poverty } \\
\text { Headcount }\end{array}$ & $\begin{array}{c}\text { Poverty } \\
\text { Gap }\end{array}$ \\
\hline \multirow{3}{*}{ Population } & Observed & 29.7 & 7.6 \\
\hline & Predicted & 33.5 & 7.9 \\
\hline & Difference* & $\uparrow \quad 3.8$ & 个 0.3 \\
\hline \multirow{3}{*}{ Urban } & Observed & 26.8 & 7.6 \\
\hline & Predicted & 28.7 & 7.2 \\
\hline & Difference* & 个 1.9 & $\begin{array}{ll}\downarrow & 0.4\end{array}$ \\
\hline \multirow{3}{*}{ Rural } & Observed & 31.5 & 7.9 \\
\hline & Predicted & 36.4 & 8.3 \\
\hline & Difference* & $\uparrow \quad 5.9$ & 0.4 \\
\hline \multirow{3}{*}{ EF accepted } & Observed & 25.9 & 6.4 \\
\hline & Predicted & 51.5 & 8.6 \\
\hline & Difference* & $\uparrow \quad 25.6$ & 2.2 \\
\hline \multirow{3}{*}{ Urban } & Observed & 27.6 & 7.6 \\
\hline & Predicted & 49.2 & 8.8 \\
\hline & Difference* & $\uparrow \quad 21.6$ & $\uparrow \quad 1.2$ \\
\hline \multirow{3}{*}{ Rural } & Observed & 25.4 & 6.0 \\
\hline & Predicted & 52.2 & 8.5 \\
\hline & Difference* & 个 26.8 & 2.5 \\
\hline
\end{tabular}

that remittances tend to reduce the poverty levels of households

Table 11 and 12 present the poverty rates, both observed and predicted, for the poverty headcount and poverty gap measures using a poverty line set at $1.72 €$ per adult equivalent per day. Poverty headcount is a measure of the percentage of households which are classified as poor. The households are classified as poor if their real monthly per adult equivalent consumption falls below the poverty line. In the scenario without migration and remittances, the estimations indicate that, if the recipient households in Kosovo did not receive remittances, poverty rates would be considerably higher for this group. The poverty headcount for the recipient households is estimated to have changed from around 26 percent observed to around 52 percent, which is an increase of 100 percent. In general, compared with the observed situation, the poverty rates would be higher in both rural and urban areas, but more so the case of the former. More precisely, the poverty rates in the rural areas would have been roughly 27 percentage points higher, representing an increase of around 105 percent in the poverty headcount rate, highlighting the dependence of many rural households on remittances.

The poverty gap is the percentage increase in consumption necessary for households to go out of poverty. The poverty gap would increase by 2.2 percentage points for the recipient households, but for all households the rate is estimated to only marginally increase. For recipient households, the poverty gap would increase in rural and urban areas although the increase would be more pronounced in the former area, more precisely in absence of remittances the rate would be 41.7 percent higher. Moreover, contrary to the observed rates, the poverty gap rate would be similar in both areas which tends to suggest that the impact of remittances is particularly high in rural areas.

Data presented in Table 12 confirm the hypothesis that remittances decrease poverty in all regions; however, the effects are considerably different between them. The poverty results across regions indicate that the poverty levels would be considerably higher in most regions, if households were not to receive remittances or send someone abroad. The highest rise is estimated to be in Mitrovica and Gjilan where the poverty headcount would respectively increase from 38.4 percent to 74.6 percent and 4.1 percent to 41.9 percent for recipient households. Gjilan has the second lowest proportion of remittance recipient 
Table 12: Observed vs. Predicted poverty headcount, extreme poverty and poverty gap across regions in percentages

\begin{tabular}{|c|c|c|c|c|c|}
\hline \multirow[b]{2}{*}{ Region } & \multirow[b]{2}{*}{ Poverty Rate } & \multicolumn{2}{|c|}{ Poverty } & \multicolumn{2}{|c|}{ Poverty Gap } \\
\hline & & All & Recipient & All & Recipient \\
\hline \multirow{3}{*}{ Gjakova } & Observed & 38.5 & 37.3 & 10.8 & 11.7 \\
\hline & Predicted & 45.5 & 66.7 & 10.6 & 11.4 \\
\hline & Difference* & 个 7.0 & 个 29.4 & $\downarrow \quad 0.2$ & $\downarrow \quad 0.3$ \\
\hline \multirow{3}{*}{ Gjilani } & Observed & 20.3 & 4.1 & 4.8 & 1.5 \\
\hline & Predicted & 25.5 & 41.2 & 5.3 & 6.5 \\
\hline & Difference* & 个 5.2 & $\uparrow \quad 37.1$ & $\uparrow \quad 0.5$ & $\uparrow \quad 5.0$ \\
\hline \multirow{3}{*}{ Mitrovica } & Observed & 43.7 & 38.4 & 12.5 & 9.5 \\
\hline & Predicted & 48.8 & 74.6 & 13.1 & 13.2 \\
\hline & Difference* & 个 5.1 & $\uparrow \quad 36.2$ & 个 1.4 & 个 9.7 \\
\hline \multirow{3}{*}{ Peja } & Observed & 30.4 & 24.1 & 8.4 & 4.5 \\
\hline & Predicted & 33.3 & 41.1 & 8.5 & 5.7 \\
\hline & Difference* & 个 2.9 & $\uparrow \quad 23.0$ & $\uparrow \quad 0.1$ & 个 1.2 \\
\hline \multirow{3}{*}{ Prizreni } & Observed & 26.1 & 20.7 & 5.3 & 4.2 \\
\hline & Predicted & 29.9 & 52.2 & 5.9 & 10.7 \\
\hline & Difference* & 个 3.8 & $\uparrow \quad 32.5$ & 个 0.6 & $\uparrow \quad 6.5$ \\
\hline \multirow{3}{*}{ Prishtina } & Observed & 15.2 & 15.6 & 3.5 & 3.0 \\
\hline & Predicted & 18.0 & 33.2 & 3.7 & 3.9 \\
\hline & Difference* & 个 3.2 & 个 17.6 & $\uparrow \quad 0.2$ & $\uparrow \quad 0.9$ \\
\hline \multirow{3}{*}{ Ferizaj } & Observed & 51.7 & 42.1 & 13.9 & 11.6 \\
\hline & Predicted & 53.2 & 59.2 & 13.6 & 11.7 \\
\hline & Difference* & 个 2.5 & $\uparrow \quad 17.1$ & $\downarrow \quad 0.3$ & $\uparrow \quad 0.1$ \\
\hline
\end{tabular}

* Difference in percentage points between observed and predicted poverty rates

households, with the majority of them belonging to the two highest consumption quintiles.

However, the results are not surprising considering the large share of remittances on total household income (more than 60 percent). In Prizren and Gjakova the poverty headcount amongst remittance receivers is considerably higher in the scenario without remittances, by around 52 and 67 percentage points respectively. The findings show that the receiving of remittances widened the poverty gap amongst households in all regions except Gjakova where in fact it decreased. In the scenario with no remittances the poverty gap would increase the most in Mitrovica (9.7 percentage points) followed by Prizren (6.5 percentage points).

\section{CONCLUSIONS}

This study estimates the impact of remittances and migration on poverty rates in the hypothetical case with no migration and remittances in Kosovo using data from the Household Budget Survey 2011. The study develops counterfactual consumption estimates for remittance recipient households through the use of econometric estimations to predict the consumption of households in the case of no remittances. A counterfactual scenario is constructed for the observed recipient households by using the estimated coefficients of the determinants of per adult equivalent annual consumption of the households that do not receive remittances from abroad. This estimation enables comparison of poverty rates, observed and 
predicted, in Kosovo and also across the regions. Due to the potential presence of selection bias, the study uses a two-stage Heckman-type selection procedure which suggests that there is no selection bias. This means that the subsample of non-migrant households in Kosovo is randomly selected from the population.

The descriptive statistics on the dependence of households on remittances (share of remittances on total household income) provides a solid basis on the assumption that remittances considerably decrease the poverty risk of recipient households. Whilst on average, household poverty levels increased in the case of no remittances, the descriptive statistics indicate that most of the recipient households belong to households in the middle- or high-income categories. Although the effect is expected to be lower, one possible explanation for this could be the large dependence of these households on remittances (at least 60 percent of total income).

The results of the impact of remittances to households' consumption support the expectations that remittances increase the consumption of recipient households. The poverty rate would be higher for a considerable proportion of households in the case of no remittances. The poverty rates would increase particularly in rural areas. Results also suggest that the poverty gap would increase in the case of no remittances in rural areas, whereas in urban areas it would experience a decrease. From a regional perspective, in the case of no remittances, the poverty gap would be higher for most but not all of the regions. The figures suggest that although it decreases the poverty levels, dependence on remittance income alone is not always sufficient to alleviate a poor household from poverty. On the other hand, policy-makers still face enormous challenges in terms of finding alternative means for addressing the persisting high levels of poverty.

Given the results of this study provides evidence on the positive effect of remittances and migration in reducing poverty in Kosovo, it is of high importance to ensure long-term sustainability of this effect. The impact of remittances on reducing poverty depends mainly on who receives remittances and how they are used. Hence, it is of the upmost importance that remittances are not used only to fund personal consumption but also are directed towards useful investments, ensuring the sustainable income generation of these households. This could be a potential way of maximising the benefits of remittances whilst decreasing the dependence of households on remittances. Therefore, in order for the effect of remittances to be sustainable even in the long-run, the government must refine policy choices in an attempt to leverage remittances for economic and investment-led development.

\section{Acknowledgments:}

This study has been supported by Think Tank Fund and published by Group for Legal and Political Studies (GLPS) as a policy report in 2015. The author has the permission of GLPS to publish the report. At the time when the report was published, the author worked as a Research Fellow at GLPS. Currently the author is the Executive Director of GLPS.

\section{REFERENCES}

Acosta, P. Fajnzylber, P. and Lopez, H. 2007. The Impact of Remittances on Poverty and Human Capital: Evidence from Latin American Household Surveys. World Bank Policy Research Working Paper No. 4247.

Acosta, P., Calderon, C., Fajnzylber, P., and Lopez, J. H., 2008. What is the Impact of International Remittances on Poverty and Inequality in Latin America?. World Development 36 (1): 89-114.

Adams, Jr. R. H., 1991. The Effects of International Remittances on Poverty, Inequality, and Development in Rural Egypt. IFPRI Research Report No. 86, Washington: IFPRI.

Adams, Jr. R. H., 2004. Remittances and Poverty in Guatemala. World Bank Policy Research Working Paper, No. 3418.

Adams, Jr. R. H., and Cuecuecha, A., 2010. The Economic Impact of International Remittances on Poverty and Household Consumption and Investment in Indonesia. World Bank Policy Research Working Paper, No. 5433.

Agarwal, M., and Dhakal, R., 2009. Socio-economic Determinants of Income Generation in the Informal Sector of Nepal - A Case of Chitwan District. Paper prepared for the Special IARIW-SAIM Conference on Measuring the Informal Economy in Developing Countries, Kathmandu, Nepal, 23-26 September.

Amuedo-Dorantes, C., and Pozo, S., 2006. Remittances as Insurance: Evidence from Mexican Immigrants. Journal of Population Economics 19 (2): 227-254.

Batista, C., and Umblijs, J., 2014. Do Migrants Send Remittances as a Way of Self Insurance? Evidence from a Representative Immigrant Survey. Institute for the Study of Labour (IZA), Discussion Paper, No. 7984.

Barham, B., and Boucher, S., 1998. Migration, Remittances and Inequality: Estimating the Net Effects of Migration on Income Distribution. Journal of Development Economics 55 (2): 307 - 331.

Bouoiyour, J., and Miftah, A., 2014. Why do Migrants remit? An insightful Analysis for Moroccan Case. CATT Université de Pau et des Pays de l'Adour (UPPA), Working Paper, No. 04.

Brown, R. P. C., and Jimenez, E., 2007. Estimating the Net Effects of Migration and Remittances on Poverty and Inequality: Comparison of Fiji and Tonga. UNU-WIDER Research Paper No. 2007/23. 
Central Bank of Kosovo. 2013. Balance of Payments Bulletin no.12.

Central Bank of Kosovo. 2019. Monthly Statistical Bulletin, no.11.

Central Bank of Kosovo. 2019. Annual Report 2018. Available at: https://www.bqk-kos.org/repository/docs/2018/CBKAR-2018.pdf

Central Bank of Kosovo. 2018. Annual Report 2017.

Deaton, A., 1997. The Analysis of Household Surveys - A Microeconometric Approach to Development Policy. Baltimore, MD: Johns Hopkins University Press.

De Brauw, A., Mueller, V., and Woldehanna, T., 2013. Motives to Remit: Evidence from Tracked Internal Migrants in Ethiopia. World Development 50: 13-23.

De la Briere., B. Sadoulet, E., de Janvry, A., and Lambert, S., 2002. The roles of destination, gender, and household composition in explaining remittances: an analysis for the Dominican Sierra. Journal of Development Economics 68: 309-328.

De Haas, H. 2009. Mobility and Human Development, Research Paper, No. 2009/01: 24-26 (United Nations Development Programme, Human Development Reports, April 2009).

European Perspective in Kosovo (EUPK) 2012 Survey. Survey of the Awareness of EU and European Integration in Kosovo.

Gubert F., Lassourd,T., and Mesple-Somps, S., 2010. Do Remittances Affect Poverty and Inequality? Evidence from Mali. Paris-Dauphine University, Document De Travail No. DT/2010-08.

Hagen-Zanker, J., 2008. Why do people migrate? A review of the theoretical literature. Munich Personal RePEc Archive (MPRA), Paper, No. 28197.

Kosovo Agency of Statistics. 2012. Results of the Household Budget Survey 2011.

Kosovo Agency of Statistics (KAS). 2013. Study on Remittances in Kosovo - 2013.

Kosovo Agency of Statistics (KAS). 2017. Consumption Poverty in the Republic of Kosovo during 2012-2015 period.

Kosovo Agency of Statistics (KAS). 2019. Labour Force Survey Results 2019.

Kosovo Agency of Statistics (KAS). 2019. Consumption Poverty in the Republic of Kosovo.

Havolli, S. 2009. Determinants of Remittances: The Case of Kosovo. Central Bank of Kosovo, Working Paper No. 3.

Heckman, J. 1979. Sample Selection Bias as a Specification Error. Econometrica 47 (1): 153-161.

Loxha, A. 2015. A Counterfactual Analysis of the Impact of Remittances on Poverty in Kosovo: An empirical Perspective. Policy Report No. 2. Group for Legal and Political Studies.

Loxha, A. 2017. The Effect of Education on Poverty in Kosovo and Albania. Doctoral thesis, Staffordshire University.
Lucas, R.E.B., and Stark, O., 1985. Motivations to Remit: Evidence from Botswana. Journal of Political Economy, 93 (5): 901-918.

Mollers, J. and Meyer, W. 2014. IZA Journal of Labor \& Development 3(16).

Nilsson, Th., 2005. Remittances and Poverty. Unpublished Master's Thesis. Lund University, School of Economics and Management.

Osili, U.O., 2007. Remittances and savings from international migration: Theory and evidence using a matched sample. Journal of Development Economics 83(I2): 446-465.

Riinvest Institute. 2007. Diaspora and Migration Policies. Prepared for Forum 2015: 27.

Rodriguez, E. and E. Tiongson 2001. Temporary Migration Overseas and Household Labor Supply: Evidence from Urban Philippines. International Migration Review 35: 1185-204.

Sorensen, N. N., 2004. Migrant Remittances as a Development Tool: The Case of Morocco. International Organization for Migration, Migration Policy Research Working Paper No. 2.

Shaorshadze, I. and Miyata, S. 2010. Foreign Remittances and Poverty Reduction in Kosovo. World Bank and UKAID Conference Western Balkans Poverty and Inclusion December 14th-15th, 2010, Brussels.

Shehaj, E. 2012. The Impact of International Migration and Remittances on Poverty in The Coastal and Mountain Region of Albania. PhD thesis Staffordshire University.

UNDP. 2012. Kosovo Remittance Study.

UNDP. 2014. Kosovo Remittance Study 2013. Available at: http://ask.rks-gov.net/publikimet/ cat_view/17-standartijetesor.

Vanwey, L.K., 2004. Altruistic and Contractual Remittances between Male and Female Migrants and Households in Rural Thailand. Demography 41(4): 739-756.

Wooldridge, J. M. 2009. Introductory Econometrics-A modern approach. 4rd edition, Thomson, pp. 174 and 759.

World Bank (WB). 2010. KOSOVO Unlocking Growth Potential: Strategies, Policies, Actions A Country Economic Memorandum. Poverty Reduction and Economic Management Unit Europe and Central Asia Region. Report No. 53185-XK.

World Bank and Statistical Institute of Kosovo. 2011. Consumption Poverty in the Republic of Kosovo in 2009. Available at: http://siteresources.worldbank.org/ INTKOSOVO/Resources/Kosovo_Poverty_for_web_eng. pdf

World Bank Data 2012; 2019. Available at: https://data. worldbank.org/indicator/bx.trf.pwkr.dt.gd.zs

Zhu, N., Luo, X., 2008. The Impact of Remittances on Rural Poverty and Inequality in China. World Bank Policy Research Working Paper No. 4637. 